\title{
RARE BOOK GIFTS AND ACQUISITIONS
}

\author{
Compiled by JANICE KRAUS
}

Ms. Kraus is the Rare Book Specialist in Special Collections and Archives, Rutgers University

This year Special Collections and Archives has acquired several significant rare books in a variety of fields. ${ }^{1}$ Many fall within the traditionally enunciated collecting areas at Rutgers; some are a slight departure. The rare book collection has been assessed to have potential in the areas of American (especially New Jersey) history; American and English literature (and included here is a growing collection of dictionaries); the natural sciences, especially botany; and accounts of visitors to foreign lands. In this last, important works in the collection are the reports of missionaries who labored in the Far East and the Americas, especially the Jesuits who were the most prolific writers of their experiences. In addition, there has been a new effort to purchase volumes or tracts produced by early masterprinters and books notable for their beauty. These are artifacts of the early period of printing and may be regarded as art objects as much as monuments to intellectual history.

Two such volumes, as renowned for their beauty as for their contents, are the Epistolae of Francesco Filelfo ( I 398-I 48 I), printed in Venice ca. I 473 by the distinguished Vindelinus da Spira; and Girolamo Squarciafico's I 48 I edition of the works of Flavius Josephus, printed in Venice by Reynaldus de Novimagio. Both volumes call to mind the highly-charged intellectual and economic atmosphere prevailing in fifteenth-century Venice, where printers allied themselves with eminent scholars and artists to produce textually reliable, elegant volumes.

Francesco Filelfo's letters, of which this volume is the first edition, reveal the many facets of a man who in his life combined great learning with the obsequious pettiness of a Renaissance courtier. Filelfo had received the usual humanistic education in Padua, Venice and Vicenza; he furthered his knowledge by spending seven years ( $1420-27$ ) in Constantinople studying Greek under the tutelage of John Chrysoloras (and married Chrysoloras' daughter Theodora). This interest in Greek led to Filelfo's lifelong acqui-

' The majority of the acquisitions for this year were purchased with money from the Charles H. ('25) and Mary Elizabeth Brower Fund. Therefore, unless otherwise specified, it may be assumed that the volumes highlighted here were bought from that fund. On behalf of Special Collections and Archives, I would like to express here our appreciation to the Brower family. 
sition of Greek manuscripts. He taught briefly in Florence and was banished by Cosimo de'Medici for intemperate remarks. Filelfo then went to the Sforza court in Milan where he spent most of the rest of his scholarly life. Late in his life he went to the court of Sixtus IV; shortly before his death Filelfo at last returned to Florence. In addition to his creative and scholarly writings, Filelfo also worked as an editor for Vindelinus da Spira who printed and published the volume of his letters Special Collections has acquired. The letters reveal a sharp-tongued polemicist, frequently inveighing against his own or his patrons' enemies or appealing for money to his patrons and friends. These missives are interlaced with classical references and overlaid with vast erudition.

The works of Flavius Josephus (born 37/38) were, like other classical writings, always items of interest to early printers. Most of the editions of Josephus' works, like the new acquisition in Special Collections, were published in the Latin translation as most people, even respected scholars, were not at home with Greek. This volume is a superb amalgamation of form and content. It was edited by Girolamo Squarciafico, a contemporary scholar who had also edited or translated the works of Petrarch, Boccaccio, Q. Asconius Pedianus and Plutarch. Reynaldus de Novimagio printed the volume $^{2}$ which in its arrangement and decoration well illustrates the dependence of early printing upon the manuscript format. This volume with its exquisite Roman type, rubrication, and richly-colored title page is an example of the high quality of Venetian printing.

Special Collections has also acquired two leaves from a Bible printed by Adolph Rusch in Strassburg ca. I 479 for the concern of Anton Koberger in Nuremberg. This Bible is the only book that can be definitely ascribed to Rusch who was the son-in-law and partner of Johann Mentelin, the first printer of Strassburg. It is printed in Gothic type with rubrication.

Another Bible (Paris, I 558) which has been acquired is the second "Benedictus" edition of the Vulgate (the first being I 54 I), named for its editor, Johannes Benedictus of Paris (ca. I 484-I 573) who sought to produce a more accurate text. There are printed marginal notations where Benedictus attempted to show where the Latin differed from the Hebrew and

2 Reynaldus' own history is interesting and illustrates the close connections among the early printers of Venice. He worked in Venice from I $477-1496$ and married a certain Paola (he was her fourth husband). Paola's second and third husbands had also been printers, the second being Johannes da Spira (the brother of Vindelinus who printed and published Filelfo's Epistolae), the man who introduced printing into Venice in I 469. 
Greek originals. The Benedictus editions were eventually placed on the $I n$ dex Expurgatorius by the faculty of theology of the University of Paris because of supposed errors in these marginal notes (Darlow \& Moule 6 I I 9n). This edition was printed by Benedict Prevost.

The work of the printer Aldus Manutius is of great importance for the history of early printing. One of his great contributions was to create a European market for Greek texts and to make publishing in Greek a regular part of the book trade. Special Collections wishes to increase its collection of Aldine imprints, both to serve as examples of the kind of scholarly editing done in the early years of printing and as examples of various type fonts used by this master-printer. To this end, Nicolas Barker's Aldus Manutius and the Development of Greek Script $E^{3}$ Type in the Fifteenth Century (Sandy Hook, Conn.: Chiswick Book Shop, I 985) has been acquired. In addition to Barker's discussion of Aldus' place in what amounted to a revolution within the publishing industry of the fifteenth and sixteenth centuries, there are also four original leaves illustrating the four different Aldine Greek types.

An interesting volume containing two disparate works, the In Quatuordecim sancti Pauli epistolas commentarius of Bishop Theodoret of Cyrus (ca. 393-457), published in Florence by Lorenzo Torrentinus in I 552, and Ludovicus Berus' Pro salutari hominis ad felicem mortem praeparatione (Basel : Johannes Oporinus, I 549, with the De fuga pestis responsio issued by Oporinus in I $55 \mathrm{I}$ appended) has been purchased. This edition of Theodoret of Cyrus, the last great theologian of Antioch and a figure of controversy in the fifth-century Church, is the first Latin edition of the commentaries on the fourteen epistles of St. Paul. They are the only surviving work of Theodoret on the New Testament and, as it is true of his other exegetical writings, are characterized by brevity and lucidity. Ludovicus Berus ( 1479 ?- I 554), a theologian and humanist, studied theology in Paris and taught it in Basel. Initially not unsympathetic to the stirrings of Protestantism in Switzerland, he soon was noted for his antipathy to the movement and when, in I 529, Catholic services were proscribed in Basel; he moved to Catholic Freiburg im Breisgau where he died in I 554. The two works of his which are included in this volume were printed in Basel, by the scholarly Johannes Oporinus (who had once worked for Froben), noted for the textual accuracy of the one thousand works he printed. That Oporinus printed Berus' work is itself interesting and illustrates the complicated situation in Basel and the catholicity of Oporinus' own situation. Both of Berus' works printed in this volume end with formal statements of 
submission to the Holy See; that Oporinus printed them in rigidly Zwinglian Basel indicates some flexibility on his part (and the city's presumably), also mirrored in his correspondence, some of which was with Catholic scholars and theologians. Around the time of Berus' publication, Oporinus' attitude had begun to harden and he and Berus had verbal and written arguments and ended their relationship. Thus the volume purchased by Special Collections calls to mind the ferment in Reformation Europe and the divided loyalties that ensued.

Pius IV (I 559-I 565), who saw to completion the Council of Trent ( 563 ), patronized the aging Michelangelo and revived the Roman University, issued the decree Revocatio omnium Indulgentiarum, quaestarum, $\xi$ aliarum facultatem, quae deferuntur per Commissarios, cum reductione illarum ad visitantes personaliter Ecclesias originales (Rome, April 25, I 56 I) which revoked the indulgences and other privileges enjoyed by many Roman churches, order and monasteries. These privileges had been intended to aid in the ransoming of captives and in providing money for converted Jews and orphans, but had been abused and, in the light of the Tridentine reforms which Pius himself had promulgated, their abolition was seen as necessary as this edict makes clear. Such privileges reverted now to the Holy See. This tract was printed by Antonio Blado and below the title the arms of Pius IV, flanked by medallions of SS. Peter and Paul (the patron saints of Rome), appear. Pius IV, as a consequence of the Council of Trent, was responsible for a new Index Librorum Prohibitorum (Rome: Paulus Manutius, 1 564) which is also in the Rare Book collection.

To the collection of dictionaries in Special Collections has been added Francesco Alunno's La fabrica de mondo . . . nella quale si contegono le voci di Dante, del Petrarca, del Boccaccio . . (Venice: Comin da Trino, I 555 ), the second edition of this work. Alunno was a grammarian and calligraphist who had written in detail on the language of Petrarch and Boccaccio. This work is divided into ten books (God, Heaven, World, Elements, Spirit, Body, Man, Qualities, Quantities, Hell), containing words used by Dante, Petrarch, Boccaccio and other early Italian writers, together with their meanings. Alunno dedicated the volume to Cosimo de'Medici. The title page is graced by a woodcut portrait of the author.

Special Collections has been steadily acquiring volumes of reports of missionaries and other travellers. Two have been purchased this year: Juan Gonzalez de Mendoza, Dell'historia della China . . . Venice: Andrea Muschio, I 586) and Giovanni Pietro Maffei, Historiarum Indicarum Libri XVI. (Bergamo: Cominus Ventura, I 590). Juan Gonzalez de Men- 
doza (born I 545), a Spanish Augustinian, compiled his history of China from the reports of Spanish Augustinian and Franciscan missionaries and included a description of that country and observation on the customs of the Chinese. His work is considered one of the first substantial accounts of China. In addition, narratives of other members of his order are present, including one on the Philippines. There is also a section on America (Mexico, Cuba, Brazil) and an account of an expedition into New Mexico. This is the first Venetian edition of the Italian translation.

Giovanni Pietro Maffei's Historia Indicarum is a discussion of European penetration into the East Indies. Drawn mainly from Jesuit letters from the missions (which it was Maffei's responsibility, as the first official historian of the order, to compile), this work was reprinted many times. It includes a section on Brazil, which has been described as very accurate.

A work of collateral interest to this area and of great importance for the history of medical botany is the Aromatum, et simplicium aliquot medicamentorum apud Indos nascentium historia (Antwerp: Christopher Plantin, I 579) of Garcia d'Orta which was acquired this year. It is the first book on oriental plants and their medicinal uses and the first textbook on tropical medicine written by a European. Gracia d'Orta (ca. I 50 I-I 56I) was a Portuguese doctor of Jewish descent who travelled widely in India and Ceylon, settling permanently in Goa in 1538 . The first edition of this work appeared there in 1563 , written in Portuguese, and was one of the first books published in India. Garcia d'Orta described each plant specimen, providing the names in the local languages as well as Greek and Arabic; he delineated their physical characteristics as well as the manner of their cultivation and preparation and the exact location of each plant. Herbal remedies are given for various maladies and Orta described several hitherto-unknown Asian diseases, among them Asian cholera and cobra bite. The edition purchased for Special Collections is the third edition of the Latin translation of Charles de l'Ecluse which provided the basis for subsequent French and Italian versions. L'Ecluse abridged the original text and added material relating to the New World as well as woodcut illustrations. The Aromatum is also important as a product of the renowned Plantin Press in Antwerp.

The Odarum Libri Sex of Jean Salmon Macrin ( I 490-I 557) which was published in Lyon in I 537 has been acquired (Alexander Library Booksale Fund). Salmon Macrin was a neo-Latin poet, called the French Horace by his contemporaries. The Odes are considered his masterpiece. $\mathrm{He}$ dedicated them to Francis I of France who is addressed in one of the odes. 
The volume also contains his Epigrammata and some religious poetry. Denis Diderot's Le Fils naturel, ou les epreuves de la vertu. Comedie. . . avec l'histoire véritable de la pièce (Amsterdam, I 757) has also been purchased through the Alexander Library Booksale Fund. This is one of two "serious" comedies written by Diderot in his attempt to establish a genre of drama existing between tragedy and comedy. The play offers a serious discussion of the problems of middle-class life and, following the play, there is a "dialogue" between Diderot and one of the characters.

The only edition of Martin Bladen Hawke's A Seaman's Remarks on the British Ships of the Line, from the Ist of Jamuary, 1756 , to the 1st of January, $1782 \ldots$ (London: Printed in the year 1782 ) has been acquired (H. Ross Fund). The British "inferiority" at sea is lamented here and there are references to the war in America and the West Indies. It is a pamphlet with much information about the Royal Navy during the North American conflict.

The Library has also received Daniel Defoe's A Friendly Rebuke to Parson Benjamin, Particularly Relating to his Quarrelling with His Own Church, and Vindicating the Dissenters. By one of the People called Quakers (London: Printed for E. Moore, I 7 I 9). Special Collections has a substantial collection of pamphlets written by Defoe.

The second edition of $A$ Catalogue of the Library Collected by Miss Richardson Currer, at Eshton Hall, Craven, Yorkshire (London, I 833) has been acquired (Sutphen Fund). Currer was England's first female bibliophile and had a collection noteworthy both for its size and quality. This edition was limited to one hundred copies. Special Collections has the presentation copy, inscribed by Currer to W. Marshall.

Special Collections has added Edmund Burke's Observations on a Late State of the Nation (London: Printed for J. Dodsley, I782) to the number of Burke's writings in our possession. It is an attack on Grenville and the project of the Stamp Act and has references to the war with France and the Canada bill. Also acquired was The Respective Pleas and Arguments of the Mother Country, and of the Colonies, Distinctly Set Forth . . . (Gloucester: Printed by R. Raikes; and sold by T. Cadell, I775) of Josiah Tucker ( 7 1 2-I 799). It is the first edition of the tract wherein Tucker argues that the American colonies would not be disputing the rights and authority of England if the French had not been driven from Canada. Tucker also refers to the Congress' "Address to the Inhabitants of the Province of Quebec," and the attempt to draw Canada into the rebellion. Another purchase was John Joseph Henry's An Accurate and Interesting Account of the Hard- 
ships and Sufferings of That Band of Heroes, Who Traversed the Wilderness in the Campaign Against Quebec in 1775 (Lancaster: Printed by William Green, I8 I2). The author, the son of the inventor William Henry of Lancaster, enlisted in Captain Matthew Smith's Company of riflemen at the beginning of the Revolution and took part in Arnold's expedition to Quebec, where he was taken prisoner and confined for nine months. After the war Henry distinguished himself as a jurist.

Special Collections has also acquired the Almanac for the Year . . I729 (Boston, I 729) of Nathaniel Ames, thus adding to an already extensive almanac collection.

Of New Jersey interest are two pamphlets. One contains the Speech of Mr. King of New Jersey on the Branch Mints. Delivered in the House of Representative, Jamuary 3I, $185 I$ (Washington, D.C. I85 I). James Gore King was a prominent lawyer and banker, President of the Erie R.R., and the New York Chamber of Commerce. In this speech King lobbied for the establishment of a mint in New York City. The second pamphlet, $A n A d-$ dress Delivered Before the New Jersey Washington Benevolent Society by James Spencer Cannon ( $1776-1852$ ), whose subject is the Society itself, is noteworthy both for its printer, Abraham Blauvelt, and its rarity in that it does not appear in Shaw and Shoemaker.

Of more contemporary interest is Special Collections' subscription to the Limited Editions Club for a second year. This series is noteworthy for the illustrations accompanying the texts of the various works reprinted.

Special Collections would like to acknowledge three gifts of rare books. The first is a group of eighty-four volumes from William Thomson Kyle (Rutgers '34) and Ruth Kyle (New Jersey College for Women '34). Among the items of interest are: Leigh Hunt's Foliage (London, 18 I 8 ); Charles Dickens' Dicken's Dictionary of London I 885 (Seventh Year); the first edition of R. R. Bowker's Copyright, Its Laws Es Its Literature (New York, 1886); the 1797 edition of the Constitutions of the Sixteen States Which Compose the Confederated Republic of America (Boston, I797); George Cruikshank, The Centenary Garland (Edinburgh, I 87 I); the third edition of John Dryden's The Hind and the Panther (London, I687); John Durant's Comfort $\mathcal{E}^{2}$ Counsell for Dejected Soules (London, I65 I); Hinton Rowan Helper, Compendium of the Impending Crisis of the South (Philadelphia, I 860); and Two Right Profitable E' Fruitful Concordances (London, I 580 ).

The second gift was received as part of the papers of Archibald S. Alexander (Ac. 3304), given by his daughter, Susan Powers. Among the items 
of interest is the first edition of William Johnson Neale's The Lost Ship (London, I 843); Seven Men by Max Beerbohm (New York, I 920) which is also a first edition and includes illustrations by the author; Toi et Moi by Paul Geraldy (Paris, I92 I) which contains two original engravings by Edouard Vuillard; several works by George Meredith, including Poems (London, I 892), Jump to Glory Jane (London, I 892) and Ballads and Poems of Tragic Life (London, I 887), all of which are first editions; and Livy's $A b$ urbe condita (Venice: Paulus Manutius, I 566).

The third gift is a very rare medical text given to Special Collections by Dr. Robert G. Fisher of the Rutgers Medical School. It is the De ischiade nervosa commentarius of Domenico Cotugno (Naples: Ex typographia Thomae Aquinatis, I775). Cotugno wrote this elegant monograph in which for the first time the "nervous" origin of sciatica is described to differentiate it from arthritis. Cotugno describes cerebrospinal fluid and the fact that it surrounds the brain and spinal cord. The first edition was published in 1764 , but all editions are quite rare. Beyond the original investigation Cotugno had made, the volume is also an example of the high standards of printing in eighteenth-century Naples. 